Jpn. J. Med. Mycol.

Vol. 28, 341-348, 1987

ISSN $0583-0516$

\title{
A Fatal Case of Pulmonary Penicilliosis
}

\author{
Takeshi Mori ${ }^{1)}$, Makiko Matsumura ${ }^{1)}$, Tomoo Kohara ${ }^{1)}$, Yoshirou Watanabe ${ }^{1)}$, \\ Taijirou Ishiyama' ${ }^{1)}$, Yoshihisa Wakabayashi ${ }^{1)}$, Hideo Ikemoto'), \\ Akiko Watanabe ${ }^{2)}$, Masataka Tanno ${ }^{3)}$, Toshikazu Shirai ${ }^{3)}$ \\ and Masakatsu Ichinoe ${ }^{4)}$
}

\begin{abstract}
Department of Internal Medicine ${ }^{1)}$, Central Laboratory for Medical Sciences, Division of Pathobiology ${ }^{21}$ and Department of Pathology ${ }^{31}$, Juntendo University School of Medicine, 2-1-1 Hongo, Bunkyo-ku, Tokyo 113, Japan Division of Microbiology ${ }^{4}$, National Institute of Hygienic Sciences, 1-18 Kamiyoga, Setagaya-ku, Tokyo 158 Japan
\end{abstract}

[Received for Publication: September 3, 1987]

A 19-year-old male developed acute lymphocytic leukemia complicated with pulmonary penicilliosis. Marked leukopenia with a high fever continued for more than two weeks. A strain of Candida glabrata was isolated from blood culture. Treatment was initiated by combination therapy with antifungal drugs and anticancer drugs. To treat the suspected infection with this fungus, oral flucytosine and intravenous miconazole were administered, but the clinical symptoms were not alleviated. Thus oral fluconazole was added to the regimen. X-ray examinations revealed that the infiltration in the middle and lower fields of the right lung gradually became localized, and the findings suggested the formation of a fungus ball. The patient died of right pneumothorax on the 66th hospital day.

At autopsy, mass lesions were detected in the thoracic cavity about $4 \times 4 \times 5 \mathrm{~cm}$ in size in the right middle lobe and about $1 \times 1 \times 3 \mathrm{~cm}$ in size in the left upper lobe. These mass lesions were filled with necrotic lung tissues, and they thus differed in nature from the so-called fungus ball. Those lesions and the cavity wall contained numerous fungal elements consisting of dichotomous septated hyphae. Two morphologically different fungi were isolated from the mass lesion in the right lung: one isolate was identified as Penicillium citrinum and the other was a Penicillium species without reaching the final identification. The morphology of these two isolates was examined in detail with an electron microscope.

This seems to be the first reported case of pulmonary penicilliosis due to P. citrinum and an unidentified Penicillium sp.

Key words: Pulmonary penicilliosis, Penicillium citrinum, scanning electron microscopy

Penicillium is usually a saprophytic and non-pathogenic organism which is widely present in the environment and often isolated from human sources. On the other hand, it is known to be a causative organism of infections of the ear, sinus, eye ${ }^{1,2)}$ and urinary tract ${ }^{31}$, endocarditis of aortic valve prosthesis ${ }^{4}$, pulmonary infections and allergic bronchopulmonary disease ${ }^{5)}$, but it very rarely causes systemic mycoses.

In this report, we describe a case of acute lymphocytic leukemia complicated with fatal penicilliosis. This is thought to be the first report of a pulmonary infection due to two different strains of Penicillium: P. citrinum and an unidentified Penicillium sp.

\footnotetext{
* To whom inquiries should be addressed.
}

\section{Case Report}

\section{A 19-year-old male:}

The patient was well prior to November of 1984, when he complained of a fever and lumbago. A local hospital suspected acute leukemia, and the patient was admitted to our hospital on December 15, 1984. Based on the results of bone marrow puncture, he was diagnosed as having acute lymphocytic leukemia and was treated with combination chemotherapy consisting of vincristine $(\mathrm{V})$, prednisolone $(\mathrm{P})$ and aclacinomycin $(\mathrm{A})$. Following the chemotherapy, he achieved complete remission and was discharged on February 5, 1985. Due to a relapse, he was readmitted from September 17 through November 2, 1985. He responded well to the VPA combination chemotherapy and a high dose of 1-aspar- 
aginase, again achieving complete remission. The third admission due to relapse was from February 10 to May 27,1986 . Treatment with vindesine, adriamycin and prednisolone, and a high dose of cytosine arabinoside achieved partial remission. The patient was discharged at his own request. However, due to repeated fever and back pain, he was readmitted on June 4, 1986. Laboratory examinations showed RBC $342 \times 10^{4} / \mathrm{mm}^{3}$, Hb 10.2 $\mathrm{g} / \mathrm{dl}$, Ht $31.1 \%$, WBC $6400 / \mathrm{mm}^{3}$ (Band 10.5, Seg 62, Lymph 12.5, Mono 4, Eosino 0.5, Baso 0.5, myelocyte 0.9 and myeloblast $9.5 \%$ ) and platelets $16.6 \times 10^{4} / \mathrm{mm}^{3}$. As a result of combination therapy with enocitabine, daunorubicin, vindesine, 6-mercaptopurine and prednisolone, the leukocyte count decreased to under $400 / \mathrm{mm}^{3}$, but the myeloblast count increased to $32 \%$. Four days later, the leukocyte count became $100 / \mathrm{mm}^{3}$, and this condition continued for 18 days and recovery of the bone marrow function was delayed. During this condition, a high fever of $38^{\circ} \mathrm{C}$ to $39^{\circ} \mathrm{C}$ persisted. From the time of admission, amphotericin B syrup (2400 mg/day) had been administered, but the fever did not abate and blood culture was positive for Candida glabrata. Chest X-ray films showed infiltration in the middle and lower fields of the right lung. These findings suggested fungal pneumonia, and therapy with miconazole $(1200 \mathrm{mg} /$ day, i.v. $)$ and flucytosine $(400 \mathrm{mg} /$ day, p.o.) was started. In spite of this combination therapy, the clinical symptoms did not subside.

Then oral fluconazole ( $100 \mathrm{mg} /$ day) was added 4 days later. Three hours after the final dosing of fluconazole administered for 10 consecutive days, the serum concentration reached a relatively high level of $7.0 \mu \mathrm{g} / \mathrm{ml}$ measured by high-performance liquid chromatography.

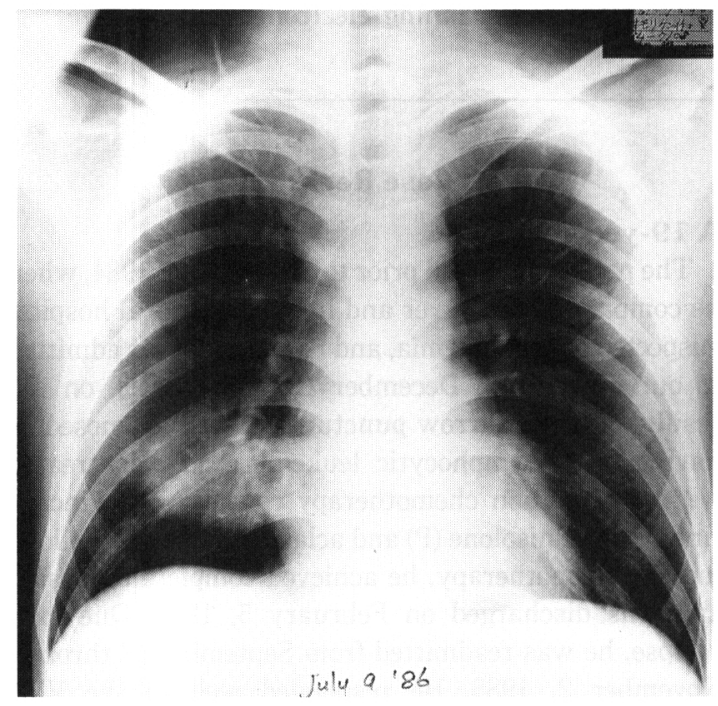

Fig. 1. Chest X-ray film taken on July 9, 1986.
The shadows in the middle and lower lung fields of the right lung gradually became localized, and their borders became apparent (Fig. 1). On July 10, a complete blood count showed a tendency for $\mathrm{WBC}$ to rise, as did myeloblasts. On July 24, chest X-rays showed a crescentshaped radiolucency surrounding the pre-existing parenchymal densities, i.e., the so-called meniscus sign. On July 28, a mass lesion was recognized in the cystic shadow, which gradually became oval and extended (Fig. 2), but the mass lesion tended to decrease in size (Fig. 3). At the same time, a small area of infiltration was seen in the left upper lung field. On August 8, the patient

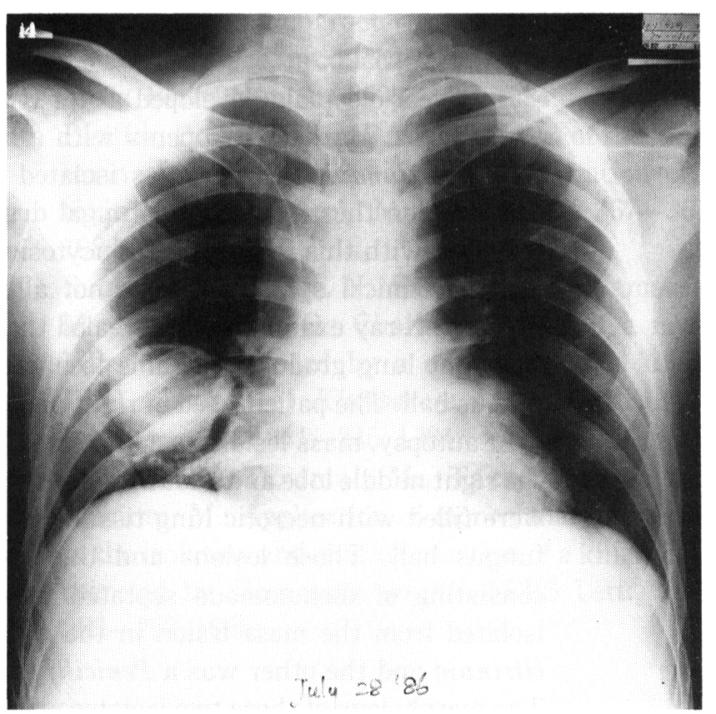

Fig. 2. Chest X-ray film taken on July 28, 1986.

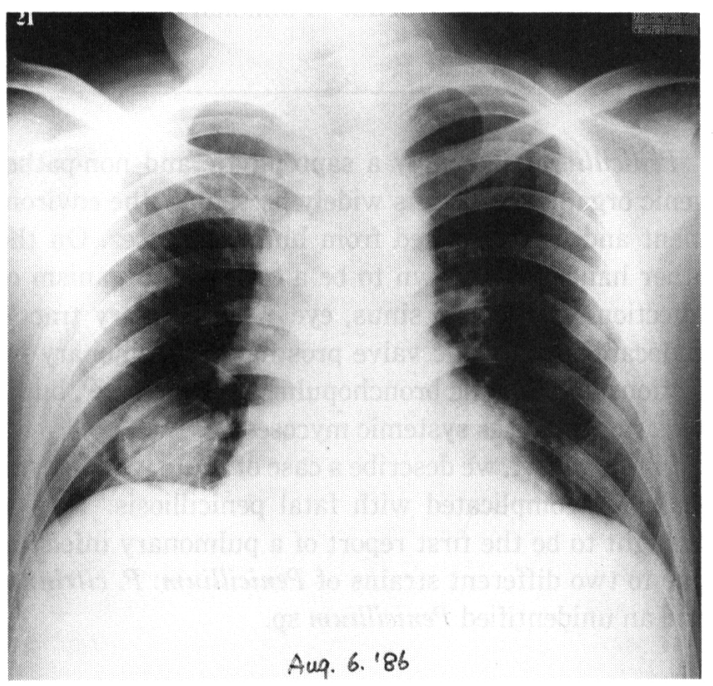

Fig. 3 Chest X-ray film taken on August 6,1986. 
suddenly complained of right colicky chest pain and dyspnea. Chest X-ray films showed right pneumothorax and deviation of the mediastinal shadow to the left. The patient's condition deteriorated, and he died due to acute respiratory failure on August 9, 1986.

\section{Autopsy Findings}

The bone marrow was found to be filled with leukemic cells, leading to a diagnosis of acute lymphocytic leukemia.

The right lung had contracted to $11 \times 4 \mathrm{~cm}$ in size. There were mass lesions in the cavities; they measured as large as $4 \times 4 \times 5 \mathrm{~cm}$ in the right middle lobe and $1 \times 1$ $\times 3 \mathrm{~cm}$ in the left upper lobe. The cause of death was considered to be rupture of the cavity wall surrounding the mass lesion in the right middle lobe (Fig. 4).

Two strains of Penicillium were isolated from the lesion in the right lung at autopsy.

In the cavity wall, a thrombosed blood vessel was seen which contained many fungal elements (Fig. 5). The mass lesions showed necrosis of the lung tissue which exposed the alveolar structure where the fungal elements penetrated the blood vessels. Thus, these lesions were considered to be clearly different from a fungus ball. The fungal elements were also seen in the wall of

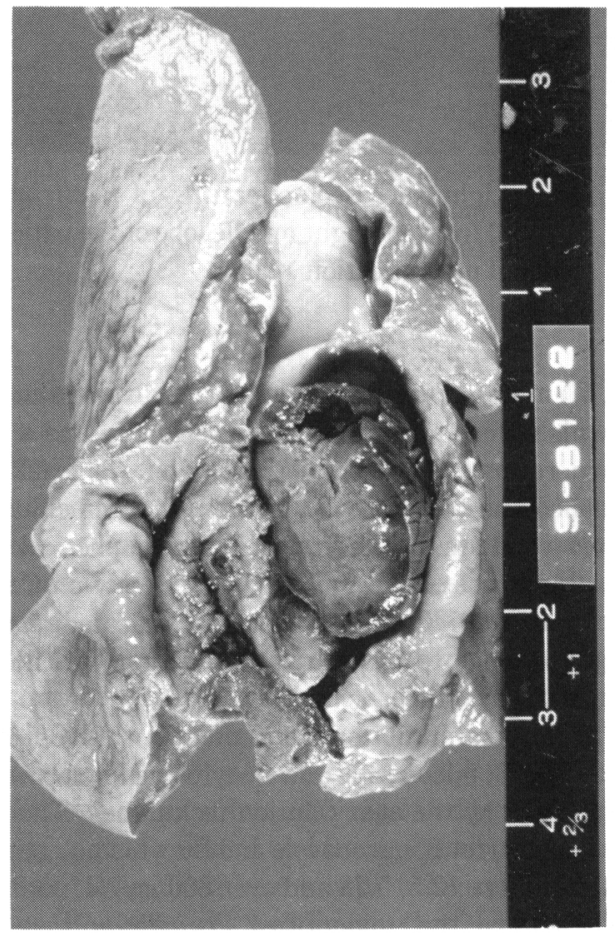

Fig. 4. Gross appearance of the right lung. Cavity wall and intracavitary mass are seen.

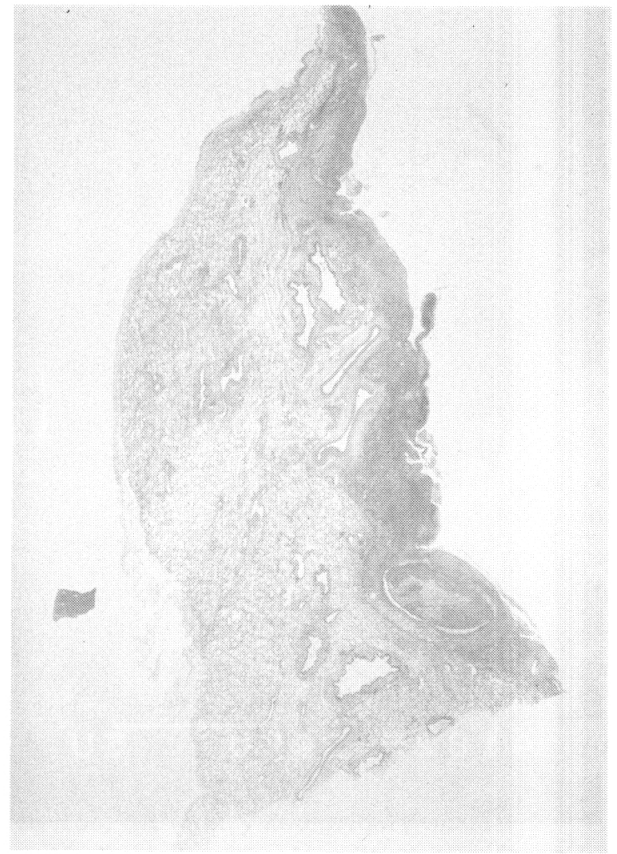

Fig. 5. Macroscopic view of the cavity wall (PAS staining).

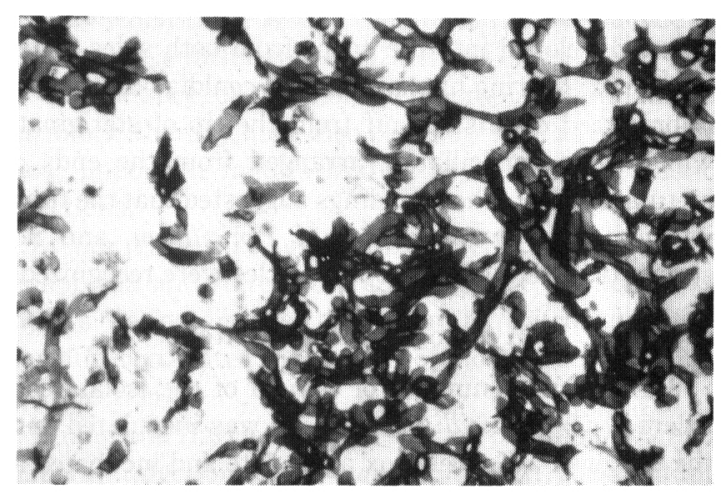

Fig. 6 Mathenamine-silver stain of the mass lesion. (original magnification $\times 200$ ).

the ectatic bronchi connected to the cavity, and they penetrated and obstructed the blood vessels in the cavity wall. In the lung tissue surrounding the cavity, leukemic cells infiltrated the alveolar septa.

A state of cytomegalic inclusion disease was observed.

The fungal elements were recognized as dichotomous branching septated hyphae (Fig. 6). Scanning electron microscopy revealed that the fungal elements in the mass lesions developed in all directions in the remaining alveolar structure. There were spaces between the 


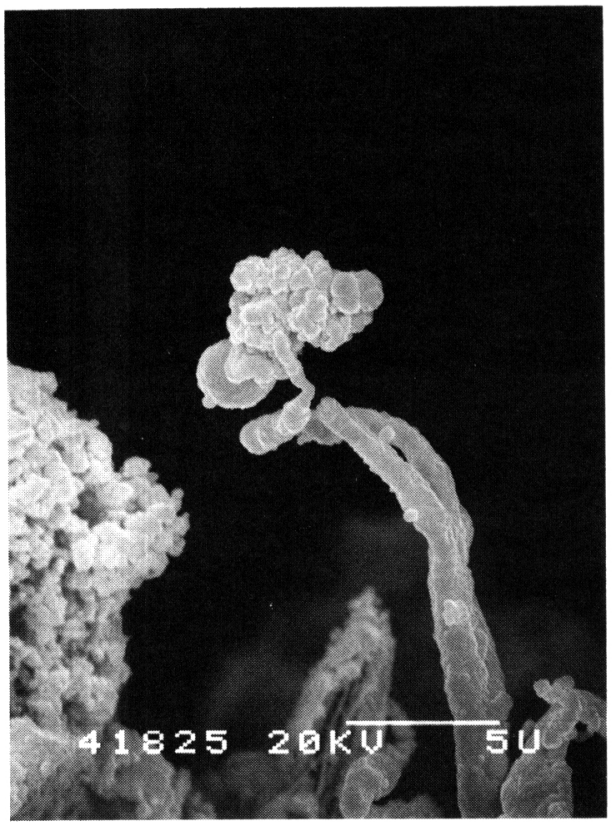

Fig. 7 Scanning electron microscopy of a fungal element developing in the space between the cavity wall and the mass lesion.

cavity wall and the mass lesions, and the fungal elements developed into the space from both sides. They were spore-bearing hyphae and had conidia occurring in unbranched chains cut off from the tip of sterigmata which were verticillately arranged from the ends of metulae (Fig. 7). These findings suggested that the fungi in the lesions were species of Penicillium, and not species of Aspergillus since no vesicles were recognized.

\section{Mycology of the Isolates}

When a small number of conidia of the isolate considered to be Penicillium citrinum was inoculated onto the center of a Czapek-Dox agar plate and incubated at $25^{\circ} \mathrm{C}$ for 2 weeks, a round, flat colony $55 \mathrm{~mm}$ in diameter developed (Fig. 8). The upper side of the colony had a blue-green color and a velvet-like appearance, of which the bottom side was yellowish-brown. The conidiophores were long $(23 \mu \mathrm{m})$, and their surface was smooth. From the end of each conidiophore, 3 to 5 verticallyarranged metulae arose to form the phialide. The conidia were oval, spherical or semi-spherical, and their surface was smooth. The periphery of the colony and its reverse were luminated and pigmented in citrinum color. This fungus grew well at $37^{\circ} \mathrm{C}$. Based on these features, this isolate was identified as Penicillium citrinum (Fig. 9).

The colony of the other isolate grown under the same culture conditions as described above was round and

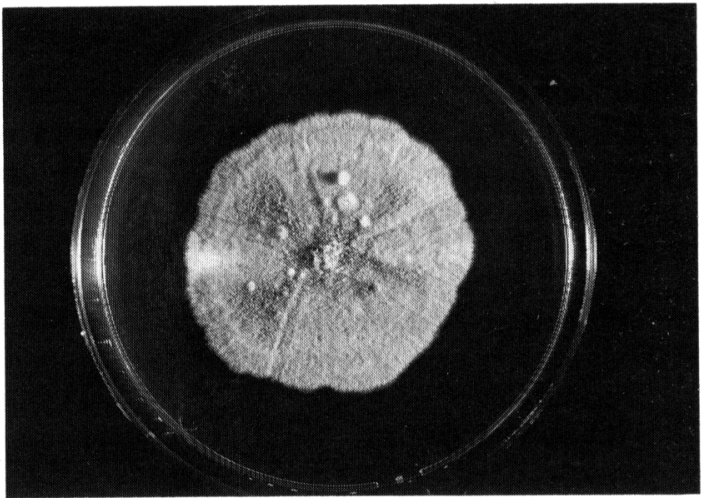

Fig. 8. Colony of P. citrinum on Czapek-dox agar after inoculation at $25^{\circ} \mathrm{C}$ for 2 weeks.

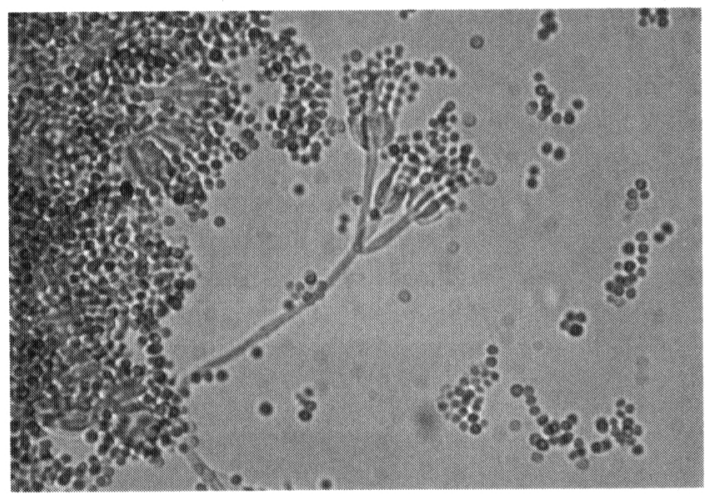

Fig. 9. Light microscopic features of $P$. citrinum cultured from the right middle lobe of the patient. (original magnification $\times 200$ )

flat, $70 \mathrm{~mm}$ in diameter (Fig. 10); the obverse showed a brownish-green surface, a white periphery and a lightbrown reverse. The conidiospores were long $(22 \mu \mathrm{m})$, branched and had smooth surfaces. The penicillus was monoverticillated. The condida were spherical with smooth surfaces. This isolate did not grow on CzapekDox agar at $37^{\circ} \mathrm{C}$. These features indicated that the fungus belongs to the genus Penicillium, but no final identification was made (Fig. 11).

The minimal inhibitory concentrations (MICs) of amphotericin $\mathrm{B}$, miconazole and flucytosine for the isolates were tested by the agar dilution technique ${ }^{6)}$. The MICs of amphotericin B, miconazole and flucytosine against $P$. citrinum were $12.5,0.78$ and over $800 \mu \mathrm{g} / \mathrm{ml}$, while the MICs against the unidentified Penicillium were 0.78 , 0.39 and $0.78 \mu \mathrm{g} / \mathrm{ml}$. However, the twenty-five percent inhibitory dose of fluconazole against the Penicillium spp. was over $80 \mu \mathrm{g} / \mathrm{ml}$ measured by the micro-liquid 


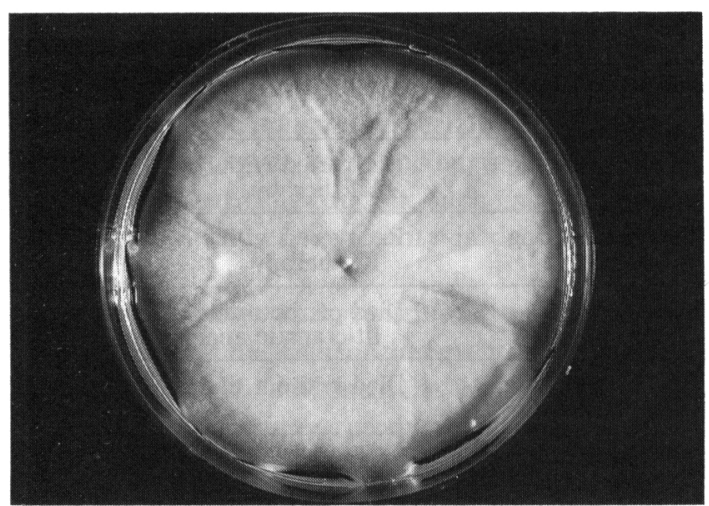

Fig. 10. Colony of unidentified Penicillium sp. after inoculation at $25^{\circ} \mathrm{C}$ for 2 weeks.

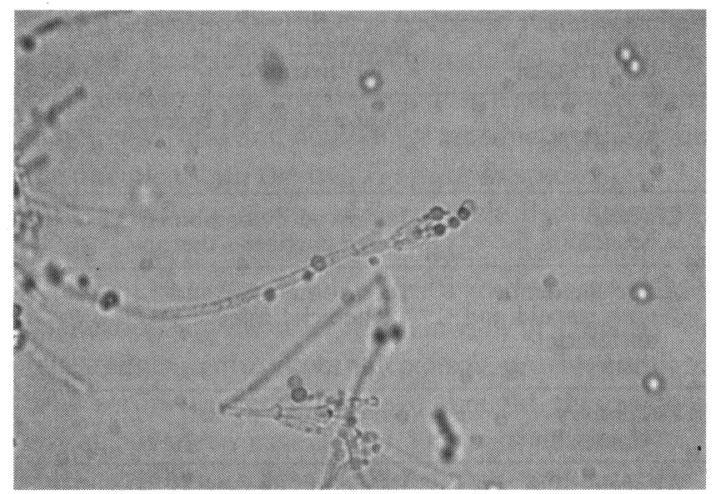

Fig. 11. Light microscopic features of unidentified Penicillium sp. cultured from the right middle lobe of the patient. (original magnification $\times 200)$

dilution method with an auto-reading system ${ }^{7)}$.

\section{Discussion}

In this case, the morphology of the fungi in the pulmonary lesions and on mash preparations closely resembled the Penicillium species detected at autopsy. Therefore, it was surmised that this case had been infected by Penicillium. Candida glabrata was detected once and disappeared after the antifungal therapy; it might have been a contaminant.

Okudaira et al. ${ }^{81}$ reported that Aspergillus and Penicillium were most frequently isolated from normally aerated lungs in cases of sudden and unexpected death or accidental death without any pathological findings in the lung. However, it is well known that the respiratory parenchyma of healthy humans is not aseptic, and that Penicillium and Aspergillus actually inhabit the normal respiratory tract. It may be justifiable to assume that these fungi can produce opportunistic infections in these organs and tissues, particularly in immunodeficient patients.

The first case of bronchopulmonary penicilliosis was reported by Castellani ${ }^{9)}$ in 1918 , and since then at least 20 cases of such infection with mycological evidence have been described in the literature (Table 1). Eight of those cases occurred before the advent of antibiotics, and the 12 cases without underlying disease or with pulmonary aspergilloma were associated with a fungus. It should be noted that all the cases with underlying diseases such as leukemia, lymphoma or systemic lupus erythematosus described in those papers ended in death.

$P$. crustaceum and P. marneffe $i$ have been reported to be the most common species isolated from human sources. Our present case seemed to be the first one with pulmonary lesions caused by two species of the genus Penicillium, i.e., P. citrinum and another Penicillium sp., and concomitant cytomegalic inclusion disease.

Gilliam and Vest $^{3)}$ reported a case of $P$. citrinum infection of the urinary tract in which the organism was isolated from the kidney and urinary bladder.

Since the introduction of antibiotics, antimetabolites and steroids, secondary mycotic infections in leukemias, lymphomas, and cancers have been increasing in number. This has been attributed to lowering of the body resistance due to these underlying diseases, particularly when there is also the undesirable influence of therapy with antimetabolites, steroids or both. Changes in the balance of the normal microbial flora due to antibiotic therapy have also been regarded as one of the most important factors leading to such opportunistic infections.

In our case also, generalized debilitation, severe leukopenia and steroid therapy might be implicated as factors that predisposed the patient to Penicillium infection and aggravated the severity of the disease, including the infection.

Huang and Harris ${ }^{10)}$ reported a case of pulmonary and cerebral infection by $P$. commune with concomitant gastrointestinal candidiasis. In penicilliosis, which resembles aspergillosis, the causative agent has been known to possess the ability to invade the blood vessels, resulting in thrombosis, hemorrhage and infarction. All of these pathological features are indistinguishable from those caused by Aspergillus.

Curtis et al. ${ }^{11)}$ described that in the vasoinvasive form of aspergillosis, thrombosis of blood vessels and infarction of the central portion of the inflammatory focus occur. With retraction of the infarcted center or resorption of necrotic tissue at the periphery, a sequestrum of devitalized lung tissue infiltrated with fungi is formed. Subsequent filling lucency by air of the space between 
Table 1. Reported Cases of Bronchopulmonary Penicilliosis

\begin{tabular}{|c|c|c|c|c|c|c|c|}
\hline No. & Author & Year & Age & Sex & $\begin{array}{l}\text { Species of } \\
\text { Penicillium }\end{array}$ & $\begin{array}{l}\text { Predisposing } \\
\text { factor }\end{array}$ & Outcome \\
\hline 1 & Castellani $^{9)}$ & 1918 & & M & P. crustaceum & $\begin{array}{l}\text { No underlying } \\
\text { disease }\end{array}$ & $\begin{array}{l}\text { Recovered with } \\
\text { KI therapy }\end{array}$ \\
\hline 2 & Giodano $^{14)}$ & 1918 & & M & P. crustaceum & $\begin{array}{l}\text { No underlying } \\
\text { disease }\end{array}$ & $\begin{array}{l}\text { Recovered with } \\
\text { KI therapy }\end{array}$ \\
\hline 3 & Pezzali15) & 1921 & & M & P. crustaceum & $\begin{array}{l}\text { Chronic } \\
\text { Bronchitis }\end{array}$ & $\begin{array}{l}\text { Died of ruptured syphi- } \\
\text { litic aortic aneurysm }\end{array}$ \\
\hline 4 & $\begin{array}{l}\mathrm{Nu} \beta \text { baum } \\
\text { et } e l^{16)}\end{array}$ & 1927 & 58 & M & $\begin{array}{l}\text { P. bicolor } \\
\text { (Fries) }\end{array}$ & $\begin{array}{l}\text { Inhalation } \\
\text { of wood dust }\end{array}$ & Died without therapy \\
\hline 5 & $\begin{array}{l}\text { Talice } \\
\quad \text { et } a l^{17)} \text {. }\end{array}$ & 1929 & 58 & $\mathrm{M}$ & P. bertai & $\begin{array}{l}\text { No underlying } \\
\text { disease }\end{array}$ & Improved by KI therapy \\
\hline 6 & $\mathrm{Nino}^{18)}$ & 1932 & 42 & $\mathrm{M}$ & P. crustaceum & $\begin{array}{l}\text { No underlying } \\
\text { disease }\end{array}$ & Improved by KI therapy \\
\hline 7 & $\begin{array}{l}\text { Aimé } \\
\quad \text { et } a l^{19)} \text {. }\end{array}$ & 1933 & 41 & $\mathrm{~F}$ & P. crustaceum & $\begin{array}{l}\text { No underlying } \\
\text { disease }\end{array}$ & Improved by KI therapy \\
\hline 8 & Da Silva ${ }^{20)}$. & 1937 & 23 & M & P. glaucum & $\begin{array}{l}\text { Inhalation } \\
\text { of corn dust }\end{array}$ & $\begin{array}{l}\text { Recovered with } \\
\text { KI therapy }\end{array}$ \\
\hline 9 & Garretón ${ }^{21)}$. & 1945 & 52 & M & $\begin{array}{l}\text { Penicillium } \\
\text { species not } \\
\text { identified }\end{array}$ & $\begin{array}{l}\text { Chronic } \\
\text { bronchitis }\end{array}$ & Improved by KI therapy \\
\hline 10 & $\begin{array}{l}\text { Delore } \\
\quad \text { et } a l^{22)}\end{array}$ & 1955 & 46 & M & P. spinulosum & $\begin{array}{l}\text { Chronic } \\
\text { bronchitis }\end{array}$ & $\begin{array}{c}\text { Improved by combined KI } \\
\text { and cortisone therapy }\end{array}$ \\
\hline 11 & $\underset{\text { et } a l^{10)}}{\text { Huang }}$ & 1962 & 42 & M & P. commune & $\begin{array}{l}\text { Acute leukemia } \\
\text { with steroid and } \\
\text { antibiotic } \\
\text { therapy }\end{array}$ & $\begin{array}{l}\text { Died of mycotic and } \\
\text { bacterial infections }\end{array}$ \\
\hline 12 & $\begin{array}{l}\text { Ikemoto } \\
\text { et } a l^{23)}\end{array}$ & 1967 & 79 & $\mathrm{M}$ & $\begin{array}{l}P . \text { nigricans } \\
(\text { A. candidus })\end{array}$ & $\begin{array}{l}\text { Pulmonary } \\
\text { aspergilloma }\end{array}$ & No therapy \\
\hline 13 & $\begin{array}{l}\text { Sahn } \\
\text { et } a l^{5)} \text {. }\end{array}$ & 1973 & 76 & M & P. rubrum & $\begin{array}{l}\text { Allergic } \\
\text { bronchopulmonary } \\
\text { penicilliosis }\end{array}$ & $\begin{array}{l}\text { Bronchial hygiene consist- } \\
\text { ing of inhalation of } \\
\text { nebulized isoetharine and } \\
\text { water }\end{array}$ \\
\hline 14 & $\begin{array}{l}\text { Liebler } \\
\quad \text { et } a l^{24)}\end{array}$ & 1977 & 34 & M & $\begin{array}{l}\text { Penicillium } \\
\text { species not } \\
\text { identified }\end{array}$ & $\begin{array}{l}\text { No underlying } \\
\text { disease }\end{array}$ & $\begin{array}{l}\text { Wedge resection of Penici- } \\
\text { llium granuloma in the } \\
\text { posterior segment of the } \\
\text { right upper lobe }\end{array}$ \\
\hline 15 & & & 6 & $\mathrm{~F}$ & P. marneffei & $\begin{array}{l}\text { No underlying } \\
\text { disease }\end{array}$ & Cured with AMPH therapy \\
\hline 16 & & & 35 & $\mathrm{M}$ & P. marneffei & Tuberculosis & Died without therapy \\
\hline 17 & $\begin{array}{l}\text { Joyanetra } \\
\text { et } a l^{25)}\end{array}$ & 1984 & 50 & $\mathrm{~F}$ & P. marneffei & $\begin{array}{l}\text { No underlying } \\
\text { disease }\end{array}$ & $\begin{array}{l}\text { Improved by combined } \\
\text { AMPH and } 5 \text {-FC therapy }\end{array}$ \\
\hline 18 & & & 38 & $\mathrm{M}$ & P. marneffei & $\begin{array}{l}\text { Lymphoprolifera- } \\
\text { tive disorder }\end{array}$ & $\begin{array}{l}\text { Died by combined AMPH } \\
\text { and } 5 \text {-FC therapy }\end{array}$ \\
\hline 19 & · & & 25 & $\mathrm{~F}$ & P. marneffei & $\begin{array}{l}\text { Systemic lupus } \\
\text { erythematosus } \\
\text { and pregnancy }\end{array}$ & Died without therapy \\
\hline 20 & $\begin{array}{l}\text { Tanphaichitra } \\
\text { et } a l^{26)} \text {. }\end{array}$ & 1984 & 60 & $\mathrm{~F}$ & P. marneffei & $\begin{array}{l}\text { Abscess with } \\
\text { granulomatous } \\
\text { inflammation; } \\
\text { osteomyelitis } \\
\text { \& salmonellosis }\end{array}$ & $\begin{array}{l}\text { Improved by combined } \\
\text { AMPH and } 5 \text {-FC therapy }\end{array}$ \\
\hline 21 & This article & 1987 & 19 & $\mathrm{M}$ & $\begin{array}{l}P . \text { citrinum and } \\
\text { unidentified } \\
\text { Penicillium } \mathrm{sp}\end{array}$ & $\begin{array}{l}\text { Acute } \\
\text { lymphocytic } \\
\text { leukemia }\end{array}$ & $\begin{array}{l}\text { Died in spite of therapy } \\
\text { with AMPH (p.o.) and } \\
\text { imidazole derivatives. }\end{array}$ \\
\hline
\end{tabular}

$\mathrm{KI}$ : potassium iodide, AMPH : amphotericin B, 5-FC: flucytosine, p.o.: oral route 
the sequestrum and peripheral lung tissue results in an air crescent, as has been observed radiographically.

In the case of functional disorders of cellular immunity and macrophages, especially in leukemia, the ability to phagocytize fungi and suppress the growth of fungi is reduced. The fungi in such cases may remain viable even when their activity is decreased by antifungal drugs.

It is well known that penicillin is obtained from $P$. notatum, and some Penicillium sp. produce mycotoxin. Mycotoxin might influence the host by suppressing immunity. P. citrinum produces citrinin, a kind of mycotoxin, which has nephrotoxicity. But in this case, renal damage was not recognized.

The activities of several antifungal drugs against $P$. citrinum and the unidentified Penicillium sp. were tested. To date, it has been said that amphotericin B is hardly absorbed by the oral route. In recent studies ${ }^{12}$, however, oral administration of high-dose amphotericin $B$ resulted in an elevated serum drug level. Nevertheless, in our case, oral amphotericin B was ineffective against the infection with the two Penicillium species.

Because flucytosine and fluconazole also showed little or no activity against our isolates, these antifungals could not be expected to achieve a good effect in clinical application. On the other hand, in view of a report ${ }^{13)}$ that repeated drip infusion of miconazole provided a significant serum concentration, we thought this might be efficacious in our case. It had, however, no effect.

It has already been reported that amphotericin B, miconazole and fluconazole, which we administerred to our patient, are all antifungals that inhibit fungi by suppressing sterol synthesis in the membranes and that the actions of these drugs are competitive with each other. The failure of these drugs to cure our case infected with Penicillium spp. might derive from their mechanism of action.

We gratefully acknowledge the kind guidance and invaluable advice provided by Dr. Kazuo Iwata, M.D., professor emeritus of Tokyo University.

\section{References}

1) Gugnani, H.C., Talwer, R.S., Njoku-Obi, A.N.U. and Kodilinye, H.C.: Mycotic keratitis in Nigeria; a study of 21 cases. Brit. J. Ophthal., 6: 607-613, 1976.

2) Eschete, M.L., King, J.W., West, B.C. and Oberle, A.: Penicillium chrysogenum endophthalmitis. Mycopathologia. 74: 125-127, 1981.

3) Gilliam, J.S. Jr. and Vest, S.A.: Penicillium infection of the urinary tract. J. Urol., 65: 484-489, 1951.

4) Upshaw, C.B.Jr.: Penicillium endocarditis of aortic valve prosthesis. J. Thorac. Cardiovasc. Surg., 68: 428-431, 1987.

5) Sahn, S.A. and Lakshminarayan, S.: Allergic bronchopulmonary penicilliosis. Chest, 63: 286-288, 1973.

6) Hiratani, T. and Yamaguchi, H.: Laboratory assessment of a systemic antimycotic miconazole (Base); in vitro activity. Chemotherapy, 32: 534540, 1984.

7) Yamaguchi, H.: in preparation.

8) Okudaira, M., Kurata, H. and Sakabe, F.: Studies on the fungal flora in the lung of human necropsy cases; a critical survey in connection with the pathogenesis of opportunistic fungal infections. Mycopathologia, 61: 3-18, 1977.

9) Castellani, A.: The higher fungi in relation to human pathology. Lancet, 1: 895-901, 1920.

10) Huang, S. and Harris, L.S.: Acute disseminated penicilliosis; report of a case and review of pertinent literature. Amer. J. Clin. Path., 39: 167-174, 1963.

11) Curtis, A.M., Walker-Smith, G.J. and Ravin, C.E.: Air crescent sign of invasive aspergillosis. Radiology, 133: 17-21, 1979.

12) Shibuya, T., Morioka, E., Ohhara, N. and Niho, Y.: Clinical study for prevention of deep fungal infection by orally administered large dose of amphotericin B. J. Jpn. Assoc. Infect. Dis., 61: 287-291, 1987.

13) Uchida, K. and Yamaguchi, H.: Bioassay for miconazole and its level in human body fluids. Chemotherapy, 32: 541-546, 1984.

14) Giodano, M.: Un caso di micosi polmonare da "Penicillium alaucum" Ann. med. nav. Roma, 2: 912-918, 1918.

15) Pezzali, G.: Contributo di casistica clinica; un caso di penicillosi del polmone secondaria. Clin. vet., 44: 201-205, 1921.

16) Naßbaum, R. and Benedek, T.: Pneumonomycosis penicillina, eine Gewerbekrankheit zum Kapitel der Lungengeschwulste. Beitr. Klin. Tuberk., 67: 756$770,1927$.

17) Talice, R.V. and Mackinnon, J.E.: Penicillium bertai (I), n. sp. agent d'une mycose broncho-pulmonaire de l'homme. Ann. parasitol., 7: 97-106, 1929.

18) Nino, F.L.: Broncomicosis penicilliar. Semana. méd., 2: 1015-1020, 1932.

19) Aimé, P., Greuzé, P. and Kresser, H.: Mycose pulmonaire à "Penicillium crustaceum" avec signes cliniques et aspect radiologique d'abcès du poumon. Presse méd., 41: 761—763, 1933.

20) Da Silva Lacaz, C.: Consideraçóes sobre um caso di penicillose pulmonar. Hospital, Rio de Janeiro., 15: 327-339, 1939. 
21) Garretón, U.I.: Un caso de bronquitis micotica a Penicillium. An. Med. Concepcion, 2: 103-105, 1945.

22) Delore, P., Coudert, J., Lambert, R. and Fayolle, J.: Un cas de mycose bronchique avec localisations musculaires septicémiques. Presse méd., 63: 1580-1582, 1955.

23) Ikemoto, H., Watanabe, K. and Hisauchi, O.: Intracavitary fungus ball; report of three new cases, including one in which both Aspergillus candidus and Penicillium nigricans were obtained by sputum culture. Jpn. J. Chest. Dis., 26: 291-296, 1967.

24) Lieber, G.A., Magovern, G.J., Sidighi, P., Park, S.B. and Cushing, W.J.: Penicillium granuloma of the lung; presenting as a solitary pulmonary nodule. JAMA., 237: 671, 1977.

25) Joyanetra, P., Nitiyanant, P., Ajello, L., Padhye, A.A., Lolekha, S., Atichartakarn, V., Vathesatogit, P., Sathaphatayavongs, B. and Prajaktam, R.: Penicilliosis marneffei in Thailand; report of five human cases. Amer. J. Trop. Med. Hyg., 33: 637644, 1984.

26) Tanphaichitra, D. and Srimuang, S.: Cellular immunity ( $T$-cell subset using monoclonal antibody) in tuberculosis, melioidosis, pasteurellosis, penicilliosis; and role of levamisole and isoprinosine. Develop. Biol. Standard, 57: 117-123, 1984. 